\title{
The Persistence of the Accruals Anomaly
}

\author{
By \\ Baruch Lev \\ New York University \\ Stern School of Business \\ (212) 998-0028 \\ blev@stern.nyu.edu \\ and \\ Doron Nissim \\ Columbia University \\ Graduate School of Business \\ (212) 854-4249 \\ dn75@columbia.edu
}

April 2004

The authors gratefully acknowledge the helpful comments and suggestions made by Stephen Penman, Jan Svejnar, and seminar participants at Columbia University, the "Share Price Accuracy and Transition Economies" Conference at Michigan University, and the University of Houston. The authors also acknowledge the research assistance of Shai Levi, and thank Brian Bushee for providing the institutional classification data. 


\title{
The Persistence of the Accruals Anomaly
}

\begin{abstract}
The accruals anomaly-the negative relationship between accounting accruals and subsequent stock returns - has been well documented in the academic and practitioner literatures for almost a decade. To the extent that this anomaly represents market inefficiency, one would expect sophisticated investors to learn about it and arbitrage the anomaly away. Yet, we show that the accruals anomaly still persists and its magnitude has not declined over time. While we find that institutional investors react promptly to accruals information, it is clear that their reaction is rather weak and is primarily characteristic of active investors who constitute a minority of institutions. The main reason: Extreme accruals firms have characteristics which are unattractive to most institutional investors. Individual investors are by and large unable to profit from trading on accruals information due to the high transaction and information costs associated with implementing a consistently profitable accruals strategy. Consequently, the accruals anomaly persists, and will probably endure.
\end{abstract}




\section{The Persistence of the Accruals Anomaly}

\section{Introduction}

Sloan's (1996) pioneering documentation of the accruals anomaly-the negative association between accounting accruals (the non-cash component of earnings) and subsequent stock returns - spawned considerable research. Specific accruals that are mostly responsible for the anomaly (primarily inventories) were identified, and the relationships between the accruals anomaly and other documented phenomena, such as the post-earnings announcement drift, have been investigated. These studies were widely disseminated among researchers and in the investment community, and, not surprisingly, it has been shown that institutional investors do react to accruals information (Collins et al., 2003): These investors hold relatively large positions in low accruals companies, and low positions in high accruals companies. Given the relatively simple exploitation strategy of the accruals anomaly_acquiring long positions in low accruals companies and short positions in high accruals companies-one would expect that sophisticated and well endowed investors will cause the anomaly to quickly dissipate and ultimately vanish.

Yet, this did not happen. We show below that the accruals anomaly persists to the present, and that its magnitude has not diminished over time. This suggests that investors' response to accruals information is either untimely or insufficient to fully arbitrage the information in accruals about future price changes. If investors' reaction is untimely, lagging the information disclosure, one would expect that the accruals anomaly will gradually decline and ultimately disappear as investors become more informed and efficient in trading on accruals information. In contrast, if the reaction is too timid, it probably indicates the existence of structural impediments to the implementation of profitable accruals strategies. To address these issues we conduct a comprehensive analysis of institutional reaction to accruals information, and 
examine the possible impediments to a vigorous trading on accruals by institutions and individual investors.

Collins et al. (2003) report that the annual change in institutional ownership is negatively related to the level of accruals in the previous year, which suggests that institutions react to the release of accruals information. However, the abnormal returns associated with accruals are mostly earned in the following year (e.g., Sloan, 1996), and start to accrue soon after the annual earnings announcement date (e.g., Collins and Hribar, 2000). Hence, it is not clear from the evidence provided by Collins et al. (2003) whether institutions react to the accruals information on a timely basis, or trade in extreme accrual firms following price changes. ${ }^{1}$ Indeed, Collins et al. (2003, page 275) state: "since we are using annual institutional holding data, results from this section should be interpreted cautiously," and Bartov (2003), in his discussion of their study suggests examining quarterly rather than annual institutional data. We follow this suggestion and examine the timeliness of institutional reaction to accruals information using quarterly institutional ownership data.

We find a negative relation between the level of accruals in a given year and the change in institutional ownership during the first quarter of the following year. That is, institutional investors react to accruals information during the quarter in which it is released. The change in institutional ownership in the second quarter of the subsequent year is also negatively and significantly related to prior year accruals, but its magnitude is smaller than that of the first quarter. The relationship between the change in institutional ownership in the third quarter and prior year accruals is insignificant. Thus, it appears that institutions trade rather promptly on the

\footnotetext{
${ }^{1}$ Prior studies have documented both momentum investing and herding behavior by institutions (e.g., Grinblatt et al., 1995; Wermers, 1999), which could lead to an untimely and protracted response of institutions to accruals information.
} 
accruals information, which suggests that the timing of institutional response is not likely to explain the persistence of the accruals anomaly.

By elimination, therefore, we conjecture that the accruals anomaly persists because the response of institutions to accruals information is too weak to effectively move prices to intrinsic values. In support of this conjecture, we find that more than half of the total institutional response to accruals is made by "transient institutions," those that trade frequently in an attempt to profit from short-term price changes. However, these investors account for only $20 \%$ of total institutional ownership of public companies. That is, most institutions appear to be only weakly active, or not active at all, in counteracting the accruals anomaly.

We then ask: Why aren't more institutions engaged in the seemingly profitable accruals strategy? We address this question by empirically identifying two profiles: that of firms with high/low accruals, and that of firms that institutional investors tend to invest in. Comparing these profiles, we find that extreme accruals firms have characteristics, such as small size and low stock price and book-to-market ratio, which institutions tend to avoid. The significant and systematic differences between the two profiles suggest that the weak response of institutions to accruals is at least partially explained by the unattractive characteristics of extreme accruals firms, which institutional investors avoid, due to prudent-person standards, liquidity concerns, and other considerations.

If institutions are restrained in their response to the accruals potential gains, why don't individual investors enter the fray and exploit the anomaly? We show that trading in the stocks of extreme accrual firms entails substantial transaction costs (broadly defined as commissions, bidask spreads, margin requirements, and the price impact of trading), likely rendering such a strategy prohibitive for individuals. We demonstrate that in order to consistently generate gross 
profits (before transaction and information costs) from an accruals strategy, the portfolios have to include a relatively large number of securities, which, due to the fixed per-transaction component of the costs, increase the burden of implementing the accruals strategy, particularly to individuals. We also show that most of the gains from an accruals strategy come from short sales of high accruals companies. These sales involve particularly large transaction costs. Consequently, individual investors are also constrained in implementing an accruals strategy.

Our findings, therefore, suggest that the accruals anomaly is not likely to be effectively arbitraged by market forces. This, however, is subject to a caveat: We document that the response of institutions to accruals information exhibited a strong positive trend during our sample period, while the accruals anomaly has not diminished. It is possible that the positive effect on market efficiency of the increased institutional response to accruals was offset by the gradual deterioration in earnings quality during the sample period (e.g., Lev and Zarowin, 1999). Thus, to the extent that the positive trend in institutional response to accruals will continue, and/or earnings quality will improve, the magnitude of the accruals anomaly may decline in the future.

Two related studies should be mentioned here. Bushee and Raedy (2003) examine the profitability of seven stock trading strategies, including the accruals anomaly. Specifically, they estimate the abnormal returns earned by the accruals strategy after deducting estimates of transaction costs, and report that the strategy generates positive abnormal returns. A unique feature of their study is the explicit consideration of several sources of transaction costs, including the price pressure of trading. Mashruwala et al. (2004) examine the consistency with which the accruals strategy yields positive abnormal returns, focusing on whether the volatility 
of the returns can be diversified away. They document substantial residual volatility which, they argue, explains the continuation of the accruals anomaly.

The remainder of the paper is organized as follows. Section 2 replicates the accruals anomaly and documents that its size did not diminish. Section 3 examines the timeliness and magnitude of institutional reaction to accruals information. Section 4 identifies the reasons for the weak response of institutions to accruals information, and Section 5 focuses on impediments to individual investors' exploitation of the accruals anomaly. Section 6 concludes the paper.

\section{The Accruals Anomaly over Time}

We start the analysis by replicating the accruals anomaly, and examining whether its magnitude has changed over time. To construct the sample, we merge the COMPUSTAT industrial, full coverage, and research files with the Center for Research in Securities Prices (CRSP) monthly files, and extract the accounting and market information required to measure accruals and abnormal returns (discussed below). Because the institutional holding data used in the primary analysis are available only for the end-of-calendar quarters, we restrict the sample to firm-year observations with December fiscal year-end. ${ }^{2}$ Our sample period spans the accruals years 1965-2002, and the stock returns range from May 1966 through December 2003 (as discussed below, stock returns are measured for the twelve months that start in May of the year following the accruals). ${ }^{3}$

\footnotetext{
${ }^{2}$ This restriction guarantees that the same information on all firms is available for each of the analyses described below.

${ }^{3}$ For the accruals year 2002, we measure returns over an eight months period, from May 1, 2003, through December 31, 2003.
} 
Following previous studies, we use two measures of accruals: the change in successive balance sheet accounts $\left(B S \_A C C\right)$, and the difference between net income and reported cash from operations (CFS_ACC). The balance sheet-based measure of accruals is calculated as in Sloan (1996):

$$
B S \_A C C=(\triangle C A-\triangle C a s h)-(\Delta C L-\triangle S T D-\Delta I T P)-D e p,
$$

Where:

$\triangle C A=$ annual change in current assets (change in COMPUSTAT data item \#4, i.e., $\Delta \# 4$ )

$\Delta$ Cash $=$ change in cash and cash equivalents $(\Delta \# 1)$

$\triangle C L \quad=$ change in current liabilities $(\Delta \# 5)$

$\triangle S T D=$ change in debt included in current liabilities $(\triangle \# 34)$

$\triangle I T P=$ change in income taxes payable $(\triangle \# 71)$

Dep = annual depreciation and amortization expense (\#14). ${ }^{4}$

The second measure of accruals, based on information from the cash flow statement, is calculated as:

$$
C F S \_A C C=E B X I-C F O,
$$

where:

EBXI = earnings before extraordinary items and discontinued operations (\#123)

CFO = net cash flow from operating activities (\#308).

Collins and Hribar (2002) report that the balance sheet approach to measuring accruals (expression 1) introduces measurement error into the accruals estimate, primarily due to mergers and acquisitions, and discontinued operations. The cash flow-based measure of accruals (2) is not affected by such corporate events, but is available only from 1988. We therefore use both

\footnotetext{
${ }^{4}$ When data items \#1, \#34, or \#71 are missing, we set their values to zero.
} 
measures in our analyses. To account for size differences across the sample firms, we scale (divide) the accruals by the average of the beginning and end-of-year book value of total assets (\#6).

We estimate abnormal (risk-adjusted) stock return as the difference between the firm's one-year holding period return and the contemporaneous return on a matched portfolio based on size (five quintiles) and book-to-market (five quintiles for each size quintile). We measure returns from May of the year following the accruals to assure that investors had access to the accruals information we examine. For securities that delisted during the holding period, proceeds from the issue are invested in the NYSE, AMEX, and NASDAQ value-weighted index until the end of the holding period. All of our results are qualitatively similar when we use size-adjusted returns, or the residual return from a cross-sectional regression of the annual stock return on beta, size, book-to-market, and the prior year return (momentum), rather than the size and book-tomarket adjusted returns used in the primary analysis. We also obtain similar results when we use 100 benchmark size and book-to-market portfolios (ten book-to-market portfolios for each size decile), instead of the twenty-five portfolios in the primary analysis.

To replicate the accruals anomaly and examine whether its magnitude has changed over time, we conduct the following analysis. For each year (1965-2002), we construct a zeroinvestment portfolio that takes a long position in the stocks of firms in the lowest decile of accruals and an equal-size short position in the stocks of firms in the highest decile of accruals. We then calculate the mean abnormal portfolio return of this zero-investment portfolio in the subsequent year (beginning in May 1). Figure 1 presents the portfolio risk-adjusted returns in each of the sample years. Returns are reported for three portfolios: (1) NYSE\&AMEX firms with extreme accruals, measured using the balance sheet approach $\left(B S \_A C C\right),(2)$ all firms with 
extreme accruals, measured using the balance sheet approach, and (3) all firms with extreme accruals, measured by the cash flow approach (CFS_ACC). We run the analysis for NYSE\&AMEX firms (first portfolio) to assure that the return patterns we identify are not due to the addition of NASDAQ firms during the 1970s. For the cash flow-based accruals, we report results using all firms only, because this measure is available since 1988 (i.e., after the introduction of NASDAQ firms).

Figure 1 indicates that for each of the three portfolios, the accruals strategy generated positive and economically significant abnormal returns in most years. Notably, the time-series of abnormal returns does not exhibit clear trends over time. To measure the size and significance of the portfolio abnormal returns and to test for temporal trends, we run the following time-series regression:

$$
P O R T_{-} R=\beta_{1}+\beta_{2} T R E N D+\varepsilon,
$$

where PORT_R is the portfolio annual abnormal return, and TREND $=0.001 \times($ year - mean year). Note that since TREND has a zero mean, the intercept $\left(\beta_{l}\right)$ reflects the time-series mean of the portfolio abnormal return. Table 1 reports the regression (3) estimates for each of the three accruals measures and stock exchange samples described above. It is evident that the mean abnormal returns of the zero-investment portfolio (bottom pair of lines), as measured by the regression intercept, are positive and highly significant in each of the three columns, with the abnormal returns ranging between $7.5 \%$ and $8.9 \%{ }^{5}$ Consistent with the visual absence of patterns in Figure 1, the coefficient on the TREND variable is insignificant in each of the three regressions, indicating that the accruals anomaly still persists and its magnitude has not changed

\footnotetext{
${ }^{5}$ These abnormal returns are slightly smaller than in Sloan (1996), due primarily to sample differences (e.g., our focus on December fiscal year-end firms) and the use of size/book-to-market adjusted returns instead of sizeadjusted returns.
} 
significantly over time. Moreover, examination of the long and short accruals positions individually (low and high accruals, respectively), presented in the top two pairs of lines in Table 1 indicates that there is no apparent trend in either side of the zero-investment strategy.

We thus conclude that the accruals anomaly persists, and its magnitude has not abated over time. These finding are surprising given that institutional investors appear to be cognizant of and trade on accruals information (Collins et al., 2003), and that their share in the capital markets has steadily increased over the sample period (Gompers and Metrick, 2001). This suggests that the institutional response to accruals information is either untimely or relatively weak. We next explore these conjectures.

\section{The Reaction of Institutional Investors to Accruals Information}

In this section we examine the reaction of institutional investors to accruals information, and in particular the timeliness of this reaction. Our research design involves regressing quarterly changes in institutional ownership on accruals and various control variables. The magnitudes, signs, and significance of the estimated accruals coefficients are used to determine the extent and timeliness of institutions' reaction to accruals information, as well as patterns over time and across types of institutions in the reaction to accruals.

\section{Methodology}

To construct the sample for this analysis, we supplement the data extracted for the stock return analysis (Section 2) with additional accounting and market information from COMPUSTAT and CRSP (discussed below), and merge these data with institutional 13(f) common stock holding information derived from Thomson Financial Securities Data. Due to 
limited availability of institutional ownership data, our sample period for this analysis covers the accruals years 1982 through 2001 .

The dependent variable in the institutional response regressions (Model 4, presented below), $\Delta I O(q, g)$, captures the change during quarter $q$ in the percentage of the firm's outstanding shares held by institutions of type $g$. We report regressions for $g$ including all institutions, as well as transient and non-transient institutions separately (defined below). We report regressions when $q$ refers to the third and fourth quarters of the accruals year, as well as when $q$ refers to the first, second, and third quarters of the subsequent year. We examine the change in institutional ownership in the last two quarters of the accruals year because some information about annual accruals can be predicted from the first three quarterly reports. However, we expect the strongest institutional reaction to take place in the first quarter of the subsequent year since most firms report annual earnings and accruals during that quarter. Some institutions may also trade on accruals information during the second quarter of the subsequent year, either because certain firms disclose complete accruals information after March 31, or due to delays in implementing a successful accruals strategy (e.g., obtaining the needed information on the level of accruals for benchmark firms, or investing gradually to reduce the price impact of trading). Such delays, however, are not likely to extend beyond the second quarter, if institutional reaction is timely. We therefore expect little or no institutional reaction in the third quarter of the subsequent year.

Institutional investors differ in their intensity of trading on fundamental information, such as the accounting accruals examined here. Bushee (1998) classifies institutional investors into three trading-intensity groups: institutions that buy securities and hold for the long haul, institutions that follow indexing strategies, and institutions that trade frequently in stocks 
attempting to profit from short term price changes ("transient institutions"). ${ }^{6}$ To the extent that accruals proxy for earnings quality (persistence) and offer profit opportunities, transient institutions are most likely to trade quickly on accruals. We accordingly examine the response to accruals of transient and non-transient institutions separately, as well as the overall institutional reaction. ${ }^{7}$ Institutional ownership is measured as the fraction of the firm's shares outstanding held by "large" institutional investors (institutions with more than $\$ 100$ million of securities under discretionary management, which are subject to the 13(f) disclosure requirements).

The explanatory (independent) variable of focus in the institutional reaction regressions (4) is the size of the accruals component of earnings (scaled by average total assets). To examine changes over time in institutional response to accruals information, we use the balance sheetbased measure of accruals $\left(B S \_A C C\right)$ described above, which is available for all sample years. For the more recent years (1988-2001), we report the sensitivity of the results when accruals are based on information from the cash flow statement $\left(C F S \_A C C\right)$. To allow for economic interpretation of the coefficient on accruals and to mitigate concerns with model specification issues (e.g., nonlinearity of the relationships, non-normality of the distribution of accruals), we replace the actual values of $B S \_A C C$ and $C F S \_A C C$ by their respective cross-sectional ranks, scaled by the number of cross-sectional observations. ${ }^{8}$

\footnotetext{
${ }^{6}$ Bushee's (1998) classification of institutional investors is based on their past investment patterns, as reflected in portfolio turnover, diversification, and momentum trading.

${ }^{7}$ We thank Brian Bushee for making his institutional classification data available to us. Classification data are available for the years 1981-1999 and are missing for a relatively few observations. For the years 2000 and 2001, we used the 1999 classification. The measurement error due to this procedure is likely to be small because the timeseries correlation in the classification scheme exceeds $80 \%$. We obtained similar results to those reported when we excluded the years 2000 and 2001 from the analysis.

${ }^{8}$ Note that as a result of applying this procedure, $B S \_A C C$ and $C F S \_A C C$ range between zero and one, with values close to one (zero) for firm-year observations with the highest (lowest) accruals in that year. As discussed below, results are qualitatively similar when we use the actual values of accruals instead of the standardized ranks.
} 
We next present the control variables in the regression of the change in institutional ownership on accruals (4). Various studies have demonstrated that institutional investors tend to hold a relatively sizeable investment in large firms (e.g., O’Brien and Bhushan, 1990; Cready, 1994; Hessel and Norman, 1992; Potter, 1992). This is attributed primarily to concerns of institutions with prudent-person standards (investment in large companies is generally considered safe), and to the preference of institutional investors for stocks with high levels of information and liquidity. We accordingly control for firm size (SIZE) in the regressions, measured by the logarithm of the market value of common equity at the end of the accruals year.

We use three additional research-based proxies for the prudence of institutional investment and availability of information about companies: firm age (AGE) - the number of years since the start of coverage by CRSP, the return on assets (ROA), and financial leverage (LEV). These controls were used in prior studies (e.g., Cready, 1994; Del Guercio, 1996; Bushee, 2001). Return on assets (ROA) is measured as operating income divided by the yearly average of total assets, and serves as a proxy for the safety of investment (profitable firms are less likely to fail). ROA also controls for the information in accruals $\left(B S \_A C C\right)$ about the level of earnings (accruals are a component of earnings, along with cash flows). The variable $L E V$, a proxy for financial risk, is measured as the ratio of the book value of debt to the sum of the book value of debt and the market value of equity at the end of the year.

Since institutions trade more frequently than individual investors and hold larger equity positions, they generally show an aversion to stocks with high transaction costs and low liquidity (e.g., Falkenstein, 1996; Gompers and Metrick, 2001). In addition to firm size, two commonly used proxies for transaction costs and liquidity are the price-per-share and share turnover (both variables are negatively related to transaction costs and positively related to liquidity). We use 
these variables as controls and define $L O G P$ as the log of the firm's price-per-share at the end of the year. Turnover $(T U R N)$ is measured as the logarithm of the annual average ratio of monthly trading volume to total shares outstanding.

Institutional investors tend to avoid shares with high idiosyncratic volatility (e.g., Shleifer and Vishny, 1997; Bushee, 2001), yet were found to invest in high beta stocks (e.g., O’Brien and Bhushan, 1990) and follow momentum strategies (e.g., Grinblatt et al., 1995). We accordingly control in regression (4) for volatility (VOLAT), BETA, and ALPHA, where BETA (ALPHA) are the market model slope (intercept) and VOLAT is the residual standard error from the market model regression, which is estimated using all available daily returns during the accruals year and the value-weighted market index. ${ }^{9}$ We further control for the book-to-market ratio $(B M)$, since many institutional investors follow either "value" or "growth" strategies, which induce a (positive or negative) correlation between institutional holdings and the book-to-market ratio (e.g., Gompers and Metrick, 2001). We also control for the dividend yield (YIELD), because institutional investors generally prefer stocks with low dividend yields and high capital gains (e.g., Cready 1994; Del Guercio 1996; Gompers and Metrick 2001).

Finally, to mitigate potential bias due to omission of correlated variables, we control in the regression for the level of ownership by institutions at the end of the previous quarter $(I O(q-$ $1, g)$ ). In addition to capturing the effect of omitted variables, $I O(q-1, g)$ may itself affect the subsequent change in institutional ownership, given that Bushee and Noe (2000) find that institutional ownership is mean reverting.

\footnotetext{
${ }^{9}$ The market model is a time series regression of the stock's return on the overall market return. The slope coefficient $B E T A$, estimated from this model, is a widely used measure of systematic risk, and the intercept $A L P H A$ indicates abnormal return.
} 
The primary regression model which includes all of the control variables described above, along with our variable of interest—accounting accruals $\left(B S \_A C C\right)$ - is:

$$
\begin{aligned}
\Delta I O(q, g)= & \alpha_{\text {industry }}+\beta B S \_A C C+\gamma_{1} S I Z E+\gamma_{2} A G E+\gamma_{3} R O A+\gamma_{4} L O G P \\
& +\gamma_{5} T U R N+\gamma_{6} B E T A+\gamma_{7} A L P H A+\gamma_{8} V O L A T+\gamma_{9} \text { YIELD } \\
& +\gamma_{10} B M+\gamma_{11} L E V+\gamma_{12} I O(q-1, g)+\varepsilon,
\end{aligned}
$$

where $\alpha_{\text {industry }}$ represents an industry-specific (two-digit SIC) intercept, and all other variables are as defined above. To mitigate the effects of potential statistical problems (e.g., model instability over-time, heteroscedasticity, cross-sectional correlation in the residual), we estimate regression (4) for each year (1982-2001) and report the time-series means and $t$-statistics of the estimated annual coefficients.

\section{Regression Estimates and Inferences}

Table 2 presents summary estimates form the cross-sectional regressions (4). ${ }^{10}$ Although all the control variables of Model (4) are included in the regressions, for parsimony we report only the accruals coefficients. ${ }^{11}$ Coefficient estimates are reported for the full sample period (1982-2001) as well as for the two subperiods 1982-1991 and 1992-2001. Focusing first on total institutional ownership (left two columns), the results for the full sample (first row in each panel) indicate that institutions do react to accruals information in the first quarter (Panel $\mathrm{C}$ ) of the subsequent year, as well as in the second quarter (Panel D), and the reaction in the former is stronger than in the latter. In each of these quarters, the coefficient of $B S \_A C C$ is negative and

\footnotetext{
${ }^{10}$ To mitigate the effect of influential observations, we delete in each analysis observations for which any of the variables in the regression lies outside the $0.5 \%-99.5 \%$ range of its sample distribution.

${ }^{11}$ Overall we find that the control variables have the expected signs consistent with prior studies. Table 4 below presents estimates from regressions of institutional ownership on the control variables.
} 
significant indicating that institutions perceive the fragility of accruals: When accruals are high, a harbinger for future earnings and stock price disappointments, institutions decrease their holdings, and vice versa for low accruals. As we expected, the change in institutional ownership in the third quarter of the subsequent year (Panel E) is unrelated to accruals. Thus, it appears that institutions react to accruals rather expeditiously and complete their reaction within two-three months after the release of the accruals information. The estimates in Panel A and B, relating to institutional reaction in the last two quarters of the accrual year, suggest that institutions as a group do not react to the accruals information contained in the quarterly reports released during the accruals year. We will see below that transient institutions are cognizant of this information.

Examination of the subperiod estimates in Table 2 suggests that the response of institutions to accruals information was much stronger during the recent period, 1992-2001, than in the prior ten years. In fact, institutional response to accruals information in the early sample years (1982-1991) is insignificant in all but the second quarter of the subsequent year, and even there the $t$-statistic is only -1.72 . In contrast, for the recent period, 1992-2001, the accruals coefficient is statistically significant in both the first and second quarters of the subsequent year, and also marginally significant in the fourth quarter of the accruals year. These findings suggest that institutional investors have largely ignored accounting accruals in their investment decisions during the 1980s, but had clearly changed their attitude during the 1990s. The accruals coefficient in the 1990 s is significant both economically and statistically. For example, the accruals coefficient for the first quarter regression (Panel C) is about 0.6, suggesting that firms reporting high (low) accruals experienced, on average, an abnormal decrease (increase) of about 0.3 percentage points in institutional ownership during the first quarter subsequent to the accruals year. 
As discussed above, institutions differ in their investment strategies and presumably in the likelihood of trading on accruals information. Accordingly, the estimates for total institutional ownership discussed so far may not indicate the extent to which active or transient institutions react to this information. Indeed, the estimates in the middle and right pairs of columns in Table 2 reveal that, for both subperiods, the reaction of transient institutions to accruals information was significant in the fourth quarter of the accruals year (Panel B), as well as in the first and second quarters of the subsequent year (Panels C and D). In contrast, nontransient ("other") institutions appear to have traded on accruals information only during the 1990s, and this trade was concentrated in the first quarter of the subsequent year. This suggests that the increase in overall institutional response to accruals information in the 1990s was due primarily to some nontransient institutions adopting active accruals strategies (or incorporating accruals information in other ways in making investment decisions).

The differences in the estimated $B S \_A C C$ coefficients over time and across institution types in Panels A through E of Tables 2 could be due in part to long-term changes in the involvement of institutional investors in capital markets. Gompers and Metrick (2001) report that institutional investors have substantially increased their share in the stock market during the 1980s and 1990s. This continuous increase in the relative magnitude of institutional trading may have contributed to the larger and more significant accruals coefficients in the 1990s observed in Table 2. To address this issue we report in Panel F of Table 2 the mean and standard deviation of ownership for each type of institutions during the two subperiods. Note that the mean of total institutional ownership during 1992-2001 is larger than that of the period 1982-1991 by a factor of 1.37 (32.16\% compared to $23.55 \%)$, while the $B S \_A C C$ coefficient for the first quarter regression (Panel C) in the 1992-2001 period is larger than in the 1982-1991 period by a factor 
of $6.23(-0.586$ compared to -0.094$)$. It seems, therefore, that the positive trend in institutional involvement in capital markets played only a secondary role, if any, in the increased reaction of institutions to accruals information during the sample period.

We suggest two non-mutually exclusive explanations for the increasing trend in the BS_ACC coefficient in Table 2 from the 1982-1991 to the 1992-2001 period. The first and obvious explanation is that institutions gradually learned about the accruals anomaly, as it was documented in the academic and practitioner literature (e.g., Sloan 1996). A second explanation is that institutions paid increasing attention to quality of earnings issues (e.g., earnings manipulation) in the 1990s - mostly involving accruals - given the SEC's increasing attention to this issue and evidence that earnings quality has deteriorated gradually during the sample period (e.g., Lev and Zarowin, 1999). ${ }^{12}$ The fact that the accruals anomaly persisted throughout the sample period (Table 1) may be due to two countervailing forces: the positive trend in the institutional response to accruals information was offset by the negative trend in earnings quality, leaving the magnitude of the accruals anomaly unchanged.

Finally, another interesting insight from Table 2 is that although transient institutions appear responsible for the majority of the institutional response to accruals information, their total investment is small relative to nontransient institutions $(6.44 \%$ for transient institutions compared with $22.46 \%$ for non-transient institutions in Panel $F$ of Table 2). That is, most institutions are only moderately active, or not active at all, in exploiting the accruals anomaly. This then raises the question: Why aren't more institutions adopting the accruals strategy? We address this question in the next section. We conclude this section with two robustness checks.

\footnotetext{
${ }^{12}$ During the 1990s, the Securities and Exchange Commission (SEC) significantly increased the pressure on public companies to curtail earnings management. As most earnings management instances do not involve cash, but rather a shift of accounting income from one period to another, they affect the level of accruals. It is highly likely that the SEC's focus on earnings quality issues was noticed by institutional investors.
} 
First, we reestimate Equation (4) measuring accruals by the cash flow approach, $C F S \_A C C$ (i.e., earnings minus cash from operations). The regression estimates with this measure of accruals are very similar to those reported in Tables 2 for the corresponding years (cash flow information is available since 1988 only). Second, we rerun the analysis using the actual ratio of accruals to average total assets instead of its cross-sectional rank. We find that the sign, significance, and time-series patterns of the accruals coefficients are all similar to those of Table 2.

\section{Why Don't Institutional Investors Eliminate the Accruals Anomaly?}

The analysis in the previous section indicates that institutions react to accruals information on a timely basis, yet, the evidence reported in Section 2 clearly indicates that the accruals anomaly persisted throughout our sample period, and continues to the present. How can these findings be reconciled? ${ }^{13}$ A potential explanation is that the response of institutional investors to accruals information is constrained because firms with extreme accruals, which afford the largest benefits from an accruals strategy, have characteristics that institutional investors tend to avoid. For example, prior studies have documented that institutional investors are more likely to trade in the stock of large companies, which are less likely to have extreme accruals. As discussed in Section 3, there are additional firm characteristics which institutional investors prefer or avoid, and these characteristics may also be related to the likelihood of having extreme accruals. Accordingly, we conduct two complementary analyses to examine whether institutions shun away from extreme accruals firms. The first analysis examines the correlations of various firm characteristics with indicators of institutional activity, and with extreme accruals.

\footnotetext{
${ }^{13}$ This puzzle is similar to that reported by Cohen et al. (2002), who examine the trading of institutions in response to earnings information and report that institutions do trade in the "right" direction but in a very conservative manner, which explains why institutional trading does not eliminate the earnings momentum anomaly.
} 
If extreme accruals firms have characteristics that institutions tend to avoid, these correlations should have opposite signs. The second analysis extends the first by using multivariate regressions, and allows us to identify the characteristics that are incrementally related to accruals and institutional ownership, which are likely to explain institutional trading vis a vis accruals information.

We use two measures of institutional activity in this analysis: (1) the level of institutional ownership at the end of the third quarter of the accruals year, and (2) the absolute value of the change in institutional ownership from the beginning of the fourth quarter of the accruals year through the end the second quarter of the subsequent year. We measure the level of institutional ownership at the end of the third quarter of the accruals year because our results in Table 2 suggest that institutions start to react to accruals information from that point of time. We measure the change in institutional ownership from the beginning of the fourth quarter of the accruals year through the end of the second quarter of the subsequent year because institutions appear to trade on accruals information most intensely during that period. To capture extreme accruals, we use an indicator variable that equals one for firm-years in the bottom or top deciles of accruals, as well as an indicator variable that equals one for firms in the top accruals decile, and an indicator variable that equals one for firms in the bottom decile.

Table 3 presents the time-series means and $t$-statistics of the cross-sectional correlations of the firm-characteristics discussed in Section 3 with: (1) the two measures of institutional activity (ownership and trading), and (2) the three measures of extreme accruals. We will comment on the correlations for institutional trading, namely the magnitude of ownership change (second column from left in Table 3), and those for extreme accruals in both the top and bottom deciles (third column from left in Table 3). As is evident from the statistical significance and 
opposite signs of the correlation coefficients, institutions prefer to trade in the stock of large companies (SIZE), while extreme accruals are prevalent in small ones. In addition, extreme accruals firms are characterized by low profitability (ROA) and price-per-share (LOGP), while institutions prefer to trade in the stock of profitable firms having high share prices. Extreme accruals firms also exhibit high residual volatility (VOLAT), while institutions prefer low volatility.

We next regress the two measures of institutional activity (level and change) and the three extreme accruals measures (five regressions) on the various firm-characteristics in Model (4), controlling for fixed industry effects. To mitigate econometric problems associated with using dichotomous dependent variables, we use the logit approach for the three extreme accruals regressions. Here too, we run the regressions for each year and report in Table 4 the time-series means and $t$-statistics of the cross-sectional coefficients. Consistent with the correlations in Table 3, we note that institutions prefer to trade in the stock of large firms (SIZE) with a high price per share $(L O G P)$, while extreme accruals firms are relatively small with low share prices. In contrast to the bivariate correlations in Table 3, profitability $(R O A)$ is now insignificantly related to institutional trading, and the relation between extreme accruals and residual volatility is only marginally significant. However, the book-to-market ratio $(B M)$ now emerges as differentiating between extreme accruals and institutional trading. It appears that institutions prefer to trade in the stocks of firms intensive in tangible assets, characterized by high book-to-market ratios, while extreme accruals are typical to intangibles-intensive firms (low $B M$ ratio).

The findings in Tables 3 and 4 thus suggest that the relatively weak response of institutions to accruals is at least partially due to the characteristics of extreme accruals firms. As institutions tend to avoid these characteristics (e.g., small size, low price-per-share and book-to- 
market ratio), the trading positions that they take in extreme accruals firms are not large enough to fully move prices to intrinsic values. Yet this mismatch between firm attributes preferred by institutions and those characterizing extreme accruals firms is unlikely to fully explain the persistence of the anomaly. We turn next to additional explanations.

\section{What about Individual Investors?}

Despite the substantial differences between the attributes of extreme accruals firms and those in which institutions tend to invest, it is doubtful that this phenomenon in and of itself is fully responsible for the persistence of the accruals anomaly. While institutions subject to prudent-person, liquidity, and other constraints may avoid extreme accruals firms, other institutions and particularly individual investors are not be subject to such institutional or contractual restrictions. In particular, given the relative simplicity of implementing the accruals strategy, one would expect individual investors to act upon it. We accordingly turn to consider another explanation for the persistence of the accruals anomaly-transaction costs (e.g., Shleifer and Vishny, 1997). We have shown above that firms with extreme accruals are relatively small with low share price and high return volatility. Such firms are generally associated with large transaction costs, consisting of commissions, margin requirements, bid-ask spread, and price impact of trading (pronounced in small, thinly traded companies). In particular, transaction costs, especially for individual investors, are a function of the number of securities in the portfolio. For a given size of investment, transaction costs increase with the number of securities involved, due to the fixed per-transaction cost component. We therefore examine the number of securities required to successfully implement an accruals investment strategy. 
Specifically, for increasing values of $\mathrm{n}$ (the number of securities in the portfolio), and for each sample year (1965 through 2002), we randomly select $1 / 2 \mathrm{n}$ securities from the low accruals decile and $1 / 2 \mathrm{n}$ securities from the high accruals decile. We then calculate the mean abnormal return in the following year of a zero-investment portfolio with equal-weights for the long (low accruals) and short (high accruals) portfolio positions. Next we calculate: (1) the $t$-statistic associated with the time-series mean of the portfolio abnormal return, and (2) the frequency of years (1965-2002) in which the portfolio abnormal return was positive. We repeat this process 500 times, and calculate the mean values across the 500 replications of the $t$-statistic and frequency of positive returns. This simulation is aimed at determining the relationship between portfolio size and the consistency of gains from implementing the accruals strategy.

Figure 2 plots the relationship between the mean $t$-statistic of abnormal returns and the number (n) of securities in the portfolio, and Figure 3 reports the relationship between the mean frequency of positive abnormal returns and the number of securities in the portfolio. ${ }^{14}$ The importance of relatively large portfolios in consistently generating gains from an accruals strategy is evident from both figures. Although the mean abnormal return across the 500 replications is $8.9 \%$ for the various values of $n$, the statistical significance (in Figure 2) and frequency of positive returns (in Figure 3) are positively and strongly related to the number of securities in the portfolio. For an investor using the accruals strategy during the sample period, the portfolios had to include close to 40 securities in each year for the returns to be statistically significant ( $t$-statistic $\geq 2.0$ ). Even then, the strategy would have resulted in positive abnormal returns (before transaction costs) in only two-thirds of the years (Figure 3). In contrast, with ten securities in the portfolio, for example, abnormal returns were positive in less than $60 \%$ of the

\footnotetext{
${ }^{14}$ Our measure of abnormal returns is the size/book-to-market adjusted returns described in Table 1. We obtain similar results when using each of the alternative approaches for measuring abnormal returns described in Section 2.
} 
years, and were statistically insignificant. The relationship of the $t$-statistic and gain frequency with the number of securities is positive and concave for all values of $\mathrm{n}$. Asymptotically, the $t$ statistic converges to 4.826 and the gain frequency converges to $79 \%$. Thus, from a starting point of 40 securities in the portfolio, substantial improvements in the consistency of gains (before transactions costs) can be obtained only through the addition of a large number of securities to the portfolio.

Figures 2 and 3 thus demonstrate the substantial number of securities and the consequent transaction costs associated with implementing an accruals strategy. They also indicate that implementing an accruals strategy requires significant information costs, because one must collect information about the accruals of a relatively large number of firms. We accordingly conclude that transaction and information costs are important impediments to a widespread trading on accruals information, particularly by individual investors, thereby contributing to the persistence of the anomaly.

Augmenting significantly the transaction costs of an accruals strategy, for both institutions and individuals, are the costs of short sales. Table 1 demonstrates that the potential gains from an accruals strategy lie mostly with the "high accruals," which require short sales. For example, for the NYSE \& AMEX firms (left column of Table 1), the average annual gain from the short sales of high accruals is $5.4 \%$, highly significant, while the gain from the low accruals is only $2.1 \%$, and barely significant. Thus, over $70 \%$ of the total gain from the zeroinvestment portfolio (long on low accruals and short on high accruals) come from the high end of accruals. Realization of this gain requires short sales whose transaction costs are very large, especially for individual investors. Ali and Trombley (2004, pp 8-11) outline the sources of these costs: 
...the short seller first locates an existing owner of the security who is willing to lend the shares. The short seller leaves collateral of 102 percent of the borrowed shares' market value and the collateral is adjusted daily on the basis of changes in market value. The borrower also pays the lender a fee, which for cash collateral transactions is embedded in the rebate rate, interest paid by the lender to the short seller... cost of short selling for retail [individual] investors is greater than that of institutional investors, because retail investors typically receive no interest on their short-sale proceeds... Besides loan fee, another potentially important shorting cost is the risk that a short position will have to be involuntarily closed due to recall of the stock loan... about $2 \%$ of shorted stocks were recalled each month.

Ali and Trombley quote estimates of the short sales loan fees, ranging between $0.20 \%$ to $4.72 \%$.

The high volume of short sales required for an accruals strategy probably renders it prohibitively costly for most individual investors.

Summarizing, the high costs of an accruals investment strategy due to the relatively large number of securities involved and the costs of short sales likely preclude most individual investors and even some institutions from implementing such a strategy.

\section{Summary}

We investigate in this study the persistence of the accruals anomaly, starting by documenting that the anomaly indeed endures to the present. We continue by exploring the reasons for the failure of institutions and individual investors to eliminate this market inefficiency. We find that institutions trade on accruals information on a timely basis, and document an increase over time in the intensity of this trade. Yet, the accruals anomaly persists despite the timely institutional response, implying that the reaction of institutions and other investors to accruals information is not strong enough to effectively move prices to intrinsic values. We suggest and provide corroborating evidence on the following explanations for the persistence of the accruals anomaly. First, extreme accruals firms have characteristics which are 
undesirable to many institutional investors who face prudent-person, liquidity, and other constraints. Accordingly, these institutions play a limited role in counteracting the accruals anomaly. Second, implementing an accruals strategy involves high transaction costs due to the large number of securities involved and the intensity of short sales. These costs are especially onerous for individual investors. Given the relative permanence of the fundamental factors inhibiting an accruals strategy, it is likely that the accruals anomaly will endure for quite some time. 


\section{References}

Ali, A.; and M. Trombley. "Short sales constraints and momentum in stock returns." Working paper, University of Arizona, 2004.

Bartov, E. "Discussion of 'Investor sophistication and the mispricing of accruals'." Review of Accounting Studies 8 (2003): 277-281.

Bushee, B. "The influence of institutional investors on myopic R\&D investment behavior." Accounting Review 73 (1998): 305-33.

Bushee, B. "Do institutional investors prefer near-term earnings over long-run value?" Contemporary Accounting Research 18 (2001): 207-246.

Bushee, B.; and C. F. Noe. "Corporate disclosure practices, institutional investors, and stock return volatility." Journal of Accounting Research 38 (2000): 171-207.

Bushee, B.; and J. S. Raedy. "Factors affecting the implementability of stock market trading strategies." Working Paper, University of Pennsylvania, 2003.

Cohen R. B.; P. A. Gompers; and T. Vuolteenaho. "Who underreacts to cash-flow news? Evidence from trading between individuals and institutions." Working Paper, National Bureau of Economic Research, Cambridge, MA, 2002.

Collins, D.; G. Gong; and P. Hribar. "Investor sophistication and the mispricing of accruals." Review of Accounting Studies 8 (2003): 251-276.

Collins, D.; and P. Hribar. "Earnings-based and accruals-based market anomalies: One effect or two?" Journal of Accounting and Economics 29 (2000): 101-123.

Collins, D.; and P. Hribar. "Errors in estimating accruals: Implications for empirical research." Journal of Accounting Research 40 (2002), 105-134.

Cready, W. M. "Determinants of relative investor demand for common stocks." Journal of Accounting, Auditing, and Finance 10 (1994): 487-507.

Del Guercio, D. "The distorting effect of the prudent-man laws on institutional equity investments.” Journal of Financial Economics 40 (1996), 31-62.

Falkenstein, E. G. "Preference for stock characteristics as revealed by mutual fund portfolio holdings." Journal of Finance 51 (1996): 111-135.

Gompers, P.; and A. Metrick. "Institutional investors and equity prices." Quarterly Journal of Economics 116 (2001): 229-259.

Grinblatt, M.; S. Titman; and R. Wermers. "Momentum investment strategies, portfolio performance, and herding: A study of mutual fund behavior." American Economic Review 85 (1995): 1088-1105. 
Hessel, C.; and M. Norman. "Financial characteristics of neglected and institutionally held stocks.” Journal of Accounting, Auditing, and Finance 7 (1992): 313-334.

Lev, B.; and P. Zarowin. "The boundaries of financial reporting and how to extend them." Journal of Accounting Research 37 (1999): 353-386.

Mashruwala, C.; S. Rajgopal; and T. Shevlin. "Why is the accruals anomaly not arbitraged away?" Working Paper, University of Washington, 2004.

O'Brien, P.; and R. Bhushan. "Analyst following and institutional ownership." Journal of Accounting Research 28 (1990), 55-82.

Potter, G. "Accounting earnings announcements, institutional investor concentration, and common stock returns.” Journal of Accounting Research 30 (1992): 146-155.

Shleifer, A.; and R. W. Vishny. "The limits of arbitrage.” Journal of Finance 52 (1997): 35-55.

Sloan, R. G. "Do stock prices fully reflect information in accruals and cash flows about future earnings?" The Accounting Review 71 (1996): 289-315.

Wermers, R. "Mutual fund herding and the impact on stock prices." Journal of Finance 54 (1999): 581-622. 


\section{Table 1}

\section{Time-series Regressions of Portfolio Abnormal Returns on an Intercept and Time Trend}

\begin{tabular}{|c|c|c|c|c|c|c|}
\hline \multirow{4}{*}{ Low accruals } & \multicolumn{2}{|c|}{$\begin{array}{l}\text { NYSE\&AMEX firms, BS } \\
\text { Approach (1965-2002) }\end{array}$} & \multicolumn{2}{|c|}{$\begin{array}{l}\text { All firms, BS Approach } \\
(1965-2002)\end{array}$} & \multicolumn{2}{|c|}{$\begin{array}{l}\text { All Firms, CFS approach } \\
\text { (1988-2002) }\end{array}$} \\
\hline & Intercept & TREND & Intercept & TREND & Intercept & TREND \\
\hline & 0.021 & -0.734 & 0.034 & 0.945 & 0.036 & 8.464 \\
\hline & 1.557 & -0.588 & 1.869 & 0.562 & 1.050 & 1.079 \\
\hline \multirow[t]{2}{*}{ High accruals } & -0.054 & -0.452 & -0.054 & -0.286 & -0.053 & 5.221 \\
\hline & -3.459 & -0.317 & -4.598 & -0.266 & -3.323 & 1.406 \\
\hline \multirow[t]{2}{*}{ Low - high } & 0.075 & -0.282 & 0.089 & 1.231 & 0.089 & 3.243 \\
\hline & 4.445 & -0.182 & 4.826 & 0.733 & 2.998 & 0.473 \\
\hline
\end{tabular}

For each regression, the first row reports the coefficients while the second row reports the $t$-statistics. PORT_AR is the mean abnormal stock return across the portfolio firms. Abnormal return is measured as the difference between the firm's return and the contemporaneous return on a matched portfolio based on size (five quintiles) and book-tomarket (five quintiles for each size quintile). Returns are measured over a twelve months period starting in May of the following year. TREND is normalized to have zero mean, so the intercept measures the time series mean of the portfolio abnormal returns. The low (high) portfolio consists of equal-size positions in the ten percent of firms with the lowest (highest) accruals. Only firms with December fiscal year end are included. Two measures of accruals are used: based on changes in balance sheet accounts (BS), and using information from the cash flows statement (CFS). 


\section{Table 2}

\section{Summary Estimates from Cross-sectional Regressions of the Change in Institutional} Ownership (IO) on Accruals and Control Variables (Model 4)

$$
\begin{aligned}
\Delta I O(q, g)= & \alpha_{\text {industry }}+\beta B S \_A C C+\gamma_{1} S I Z E+\gamma_{2} A G E+\gamma_{3} R O A+\gamma_{4} L O G P \\
& +\gamma_{5} T U R N+\gamma_{6} B E T A+\gamma_{7} A L P H A+\gamma_{8} V O L A T+\gamma_{9} \text { YIELD } \\
& +\gamma_{10} B M+\gamma_{11} L E V+\gamma_{12} I O+\varepsilon
\end{aligned}
$$

\begin{tabular}{|c|c|c|c|c|c|c|c|}
\hline & \multicolumn{2}{|c|}{ Total Inst. } & \multicolumn{2}{|c|}{ Transient } & \multicolumn{2}{|c|}{ Other } & \multirow[b]{2}{*}{$\operatorname{Mean}(\mathrm{N})$} \\
\hline & $\operatorname{Mean}(\beta)$ & $\mathrm{t}(\beta)$ & $\operatorname{Mean}(\beta)$ & $\mathrm{t}(\beta)$ & $\operatorname{Mean}(\beta)$ & $\mathrm{t}(\beta)$ & \\
\hline $1982-2001$ & 0.094 & 1.057 & -0.039 & -0.896 & 0.140 & 1.902 & 2,166 \\
\hline 1982-1991 & -0.089 & -0.880 & -0.039 & -0.584 & -0.030 & -0.311 & 1,627 \\
\hline $1992-2001$ & 0.276 & 2.220 & -0.038 & -0.656 & 0.309 & 3.649 & 2,706 \\
\hline
\end{tabular}

Panel A: Dependent variable is the change in IO during the third quarter of the year

\begin{tabular}{|c|c|c|c|c|c|c|c|}
\hline & \multicolumn{2}{|c|}{ Total Inst. } & \multicolumn{2}{|c|}{ Transient } & \multicolumn{2}{|c|}{ Other } & \multirow[b]{2}{*}{$\operatorname{Mean}(\mathrm{N})$} \\
\hline & $\operatorname{Mean}(\beta)$ & $\mathrm{t}(\beta)$ & $\operatorname{Mean}(\beta)$ & $\mathrm{t}(\beta)$ & $\operatorname{Mean}(\beta)$ & $\mathrm{t}(\beta)$ & \\
\hline $1982-2001$ & -0.098 & -0.950 & -0.200 & -3.653 & 0.110 & 1.294 & 2,219 \\
\hline 1982-1991 & 0.021 & 0.131 & -0.196 & -2.384 & 0.203 & 1.357 & 1,655 \\
\hline 1992-2001 & -0.217 & -1.659 & -0.204 & -2.659 & 0.016 & 0.210 & 2,783 \\
\hline
\end{tabular}

Panel B: Dependent variable is the change in IO during the fourth quarter of the year

\begin{tabular}{|c|c|c|c|c|c|c|c|}
\hline & \multicolumn{2}{|c|}{ Total Inst. } & \multicolumn{2}{|c|}{ Transient } & \multicolumn{2}{|c|}{ Other } & \multirow[b]{2}{*}{$\operatorname{Mean}(\mathrm{N})$} \\
\hline & $\operatorname{Mean}(\beta)$ & $\mathrm{t}(\beta)$ & $\operatorname{Mean}(\beta)$ & $\mathrm{t}(\beta)$ & $\operatorname{Mean}(\beta)$ & $\mathrm{t}(\beta)$ & \\
\hline $1982-2001$ & -0.340 & -3.040 & -0.248 & -4.307 & -0.181 & -1.542 & 2,066 \\
\hline 1982-1991 & -0.094 & -1.126 & -0.229 & -2.660 & 0.064 & 0.471 & 1,592 \\
\hline $1992-2001$ & -0.586 & -3.254 & -0.268 & -3.308 & -0.426 & -2.640 & 2,541 \\
\hline
\end{tabular}

Panel C: Dependent variable is the change in IO during the first quarter of the subsequent year

\begin{tabular}{|c|c|c|c|c|c|c|c|}
\hline & \multicolumn{2}{|c|}{ Total Inst. } & \multicolumn{2}{|c|}{ Transient } & \multicolumn{2}{|c|}{ Other } & \multirow[b]{2}{*}{$\operatorname{Mean}(\mathrm{N})$} \\
\hline & $\operatorname{Mean}(\beta)$ & $\mathrm{t}(\beta)$ & $\operatorname{Mean}(\beta)$ & $\mathrm{t}(\beta)$ & $\operatorname{Mean}(\beta)$ & $\mathrm{t}(\beta)$ & \\
\hline $1982-2001$ & -0.259 & -2.778 & -0.263 & -7.058 & -0.035 & -0.384 & 2,056 \\
\hline 1982-1991 & -0.161 & -1.723 & -0.173 & -3.039 & -0.014 & -0.131 & 1,585 \\
\hline $1992-2001$ & -0.358 & -2.223 & -0.353 & -12.293 & -0.057 & -0.361 & 2,528 \\
\hline
\end{tabular}

Panel D: Dependent variable is the change in IO during the second quarter of the subsequent year

\begin{tabular}{|c|c|c|c|c|c|c|c|}
\hline & \multicolumn{2}{|c|}{ Total Inst. } & \multicolumn{2}{|c|}{ Transient } & \multicolumn{2}{|c|}{ Other } & \multirow[b]{2}{*}{$\operatorname{Mean}(\mathrm{N})$} \\
\hline & $\operatorname{Mean}(\beta)$ & $\mathrm{t}(\beta)$ & $\operatorname{Mean}(\beta)$ & $\mathrm{t}(\beta)$ & $\operatorname{Mean}(\beta)$ & $\mathrm{t}(\beta)$ & \\
\hline $1982-2001$ & -0.062 & -0.667 & -0.123 & -2.134 & 0.008 & 0.154 & 2,044 \\
\hline 1982-1991 & -0.094 & -0.868 & -0.127 & -1.534 & 0.001 & 0.038 & 1,577 \\
\hline $1992-2001$ & -0.030 & -0.193 & -0.120 & -1.406 & 0.014 & 0.146 & 2,511 \\
\hline
\end{tabular}

Panel E: Dependent variable is the change in IO during the third quarter of the subsequent year 
Panel F: Institutional ownership at the end of the third quarter by group and over time

\begin{tabular}{|c|c|c|c|c|c|c|c|}
\hline & \multicolumn{2}{|c|}{ Total Inst. } & \multicolumn{2}{|c|}{ Transient } & \multicolumn{2}{|c|}{ Other } & \multirow[b]{2}{*}{$\mathrm{N}$} \\
\hline & Mean & Std Dev. & Mean & Std Dev. & Mean & Std Dev. & \\
\hline $1982-2001$ & 28.90 & 23.92 & 6.44 & 7.83 & 22.46 & 19.08 & 40,629 \\
\hline 1982-1991 & 23.55 & 20.56 & 5.15 & 6.61 & 18.40 & 16.58 & 15,368 \\
\hline $1992-2001$ & 32.16 & 25.21 & 7.23 & 8.39 & 24.93 & 20.06 & 25,261 \\
\hline
\end{tabular}

The regressions in Panels A through E include all the explanatory variables but, for parsimony, summary statistics (time series mean and $t$-statistic) are reported only for the accruals coefficient. The dependent variables, $\Delta I O(q, g)$, measure the change in ownership by institutional group $g$ ( $g=$ all institutions, transient institutions, and other) during quarter $q(q=$ third and fourth quarters of the accruals year and the first, second and third quarters of the subsequent year). Ownership is expressed in percentage points. SIZE is the logarithm of market value of equity at the end of the year. $A G E$ is the number of years since the start of coverage period by CRSP. ROA is operating income divided by average total assets during the year. LOGP is the logarithm of price per share at the end of the year. TURN is the logarithm of the average ratio during the year of monthly trading volume to total shares outstanding. BETA (ALPHA) is the market model slope (intercept), estimated using all available daily returns during the year and the value-weighted market index. VOLAT is the residual standard error from the market model regression. YIELD is the dividend yield, measured as the total amount of dividends declared on common stock during the year divided by the market value of equity at the end of the year. $B M$ is the ratio of book value to market value of common equity at the end of the year. $L E V$ is the ratio of the book value of debt to the market value of capital (book value of debt plus market value of equity). $I O$ is the level of institutional ownership at the beginning of the quarter. 
Table 3

Time-series Means and $t$-statistics of Cross-sectional Correlations of Firm-Characteristics with Measures of Institutional Activity and Extreme Accruals

\begin{tabular}{|c|c|c|c|c|c|}
\hline \multirow{3}{*}{ SIZE } & \multicolumn{2}{|c|}{ Institutions } & \multicolumn{3}{|c|}{ Accruals } \\
\hline & Holding & Trading & Extreme & High & Low \\
\hline & $\begin{array}{c}0.65 \\
116.56\end{array}$ & $\begin{array}{c}0.18 \\
14.91\end{array}$ & $\begin{array}{c}-0.23 \\
-31.13\end{array}$ & $\begin{array}{c}-0.13 \\
-26.04\end{array}$ & $\begin{array}{c}-0.18 \\
-23.66\end{array}$ \\
\hline AGE & $\begin{array}{c}0.33 \\
16.95\end{array}$ & $\begin{array}{l}-0.04 \\
-2.30\end{array}$ & $\begin{array}{c}-0.18 \\
-24.82\end{array}$ & $\begin{array}{c}-0.15 \\
-19.37\end{array}$ & $\begin{array}{c}-0.09 \\
-15.88\end{array}$ \\
\hline ROA & $\begin{array}{c}0.31 \\
51.51\end{array}$ & $\begin{array}{l}0.09 \\
9.26\end{array}$ & $\begin{array}{c}-0.14 \\
-11.97\end{array}$ & $\begin{array}{l}0.03 \\
3.69\end{array}$ & $\begin{array}{c}-0.22 \\
-24.19\end{array}$ \\
\hline LOGP & $\begin{array}{c}0.63 \\
143.29\end{array}$ & $\begin{array}{c}0.19 \\
21.65\end{array}$ & $\begin{array}{c}-0.23 \\
-22.32\end{array}$ & $\begin{array}{c}-0.08 \\
-10.40\end{array}$ & $\begin{array}{c}-0.23 \\
-25.91\end{array}$ \\
\hline TURN & $\begin{array}{c}0.22 \\
10.13\end{array}$ & $\begin{array}{c}0.24 \\
19.43\end{array}$ & $\begin{array}{l}0.10 \\
8.86\end{array}$ & $\begin{array}{c}0.12 \\
10.02\end{array}$ & $\begin{array}{l}0.01 \\
0.99\end{array}$ \\
\hline BETA & $\begin{array}{l}0.25 \\
9.80\end{array}$ & $\begin{array}{c}0.15 \\
16.01\end{array}$ & $\begin{array}{l}0.04 \\
3.03\end{array}$ & $\begin{array}{l}0.05 \\
4.77\end{array}$ & $\begin{array}{l}-0.01 \\
-0.60\end{array}$ \\
\hline ALPHA $\times 100$ & $\begin{array}{l}-0.09 \\
-3.92\end{array}$ & $\begin{array}{l}0.05 \\
7.17\end{array}$ & $\begin{array}{l}0.01 \\
0.87\end{array}$ & $\begin{array}{l}0.05 \\
4.38\end{array}$ & $\begin{array}{l}-0.03 \\
-2.17\end{array}$ \\
\hline VOLAT & $\begin{array}{c}-0.48 \\
-43.18\end{array}$ & $\begin{array}{l}-0.09 \\
-9.51\end{array}$ & $\begin{array}{c}0.24 \\
46.02\end{array}$ & $\begin{array}{c}0.11 \\
23.00\end{array}$ & $\begin{array}{c}0.22 \\
28.31\end{array}$ \\
\hline YIELD & $\begin{array}{c}0.17 \\
11.91\end{array}$ & $\begin{array}{l}-0.03 \\
-2.81\end{array}$ & $\begin{array}{c}-0.19 \\
-20.27\end{array}$ & $\begin{array}{c}-0.14 \\
-15.21\end{array}$ & $\begin{array}{c}-0.12 \\
-18.76\end{array}$ \\
\hline $\mathrm{BM}$ & $\begin{array}{l}-0.09 \\
-6.42\end{array}$ & $\begin{array}{l}-0.07 \\
-8.75\end{array}$ & $\begin{array}{l}-0.06 \\
-6.81\end{array}$ & $\begin{array}{l}-0.09 \\
-9.34\end{array}$ & $\begin{array}{l}0.01 \\
0.88\end{array}$ \\
\hline LEV & $\begin{array}{l}-0.02 \\
-1.35\end{array}$ & $\begin{array}{l}-0.01 \\
-1.02\end{array}$ & $\begin{array}{l}-0.07 \\
-8.05\end{array}$ & $\begin{array}{c}-0.10 \\
-10.26\end{array}$ & $\begin{array}{l}0.00 \\
0.28\end{array}$ \\
\hline
\end{tabular}

For each variable, the first (second) row reports the time-series mean ( $t$-statistic) of the cross-sectional correlation coefficient. The average number of observations per year is 2,059. The sample period is 1982-2001. "Holding" is the level of institutional ownership at the end of the third fiscal quarter. "Trading" is the absolute value of the change in institutional ownership during the nine months starting at the beginning of the fourth quarter. "Extreme" is an indicator variable that equals one for firm-years in the bottom or top deciles of accruals in that year. "High" is an indicator variable that equals one for firms in the top accruals decile. "Low" is an indicator variable that equals one for firms in the bottom decile. The other variables are described in Table 2. 


\section{Table 4}

\section{Summary Statistics from Cross-sectional Regressions Examining the Firm-Characteristics Preferred by Institutions and Common for Extreme Accruals Firms}

\begin{tabular}{|c|c|c|c|c|c|}
\hline \multirow{3}{*}{$\begin{array}{l}\text { Dep. variable: } \\
\text { SIZE }\end{array}$} & \multicolumn{2}{|c|}{ Institutions (OLS) } & \multicolumn{3}{|c|}{ Accruals (Logit) } \\
\hline & Holding & Trading & Extreme & High & Low \\
\hline & $\begin{array}{c}4.741 \\
28.812\end{array}$ & $\begin{array}{l}0.464 \\
5.644\end{array}$ & $\begin{array}{c}-0.230 \\
-11.386\end{array}$ & $\begin{array}{c}-0.343 \\
-14.289\end{array}$ & $\begin{array}{l}-0.114 \\
-4.473\end{array}$ \\
\hline AGE & $\begin{array}{c}0.099 \\
11.152\end{array}$ & $\begin{array}{l}-0.061 \\
-7.370\end{array}$ & $\begin{array}{l}-0.015 \\
-8.527\end{array}$ & $\begin{array}{l}-0.039 \\
-8.668\end{array}$ & $\begin{array}{l}0.003 \\
0.944\end{array}$ \\
\hline ROA & $\begin{array}{l}3.906 \\
5.088\end{array}$ & $\begin{array}{l}0.446 \\
1.305\end{array}$ & $\begin{array}{l}-0.249 \\
-2.008\end{array}$ & $\begin{array}{l}2.020 \\
6.712\end{array}$ & $\begin{array}{l}-2.104 \\
-8.326\end{array}$ \\
\hline LOGP & $\begin{array}{c}5.798 \\
19.827\end{array}$ & $\begin{array}{l}0.759 \\
7.546\end{array}$ & $\begin{array}{l}-0.097 \\
-2.678\end{array}$ & $\begin{array}{l}0.079 \\
2.255\end{array}$ & $\begin{array}{l}-0.198 \\
-4.334\end{array}$ \\
\hline TURN & $\begin{array}{l}4.973 \\
7.742\end{array}$ & $\begin{array}{l}2.272 \\
8.970\end{array}$ & $\begin{array}{l}0.267 \\
6.839\end{array}$ & $\begin{array}{l}0.325 \\
5.163\end{array}$ & $\begin{array}{l}0.013 \\
0.319\end{array}$ \\
\hline BETA & $\begin{array}{l}-1.032 \\
-1.467\end{array}$ & $\begin{array}{l}-0.014 \\
-0.101\end{array}$ & $\begin{array}{l}0.130 \\
4.870\end{array}$ & $\begin{array}{l}0.176 \\
3.117\end{array}$ & $\begin{array}{l}0.079 \\
1.501\end{array}$ \\
\hline ALPHA $\times 100$ & $\begin{array}{c}-8.983 \\
-11.405\end{array}$ & $\begin{array}{l}2.071 \\
6.291\end{array}$ & $\begin{array}{l}-0.013 \\
-0.182\end{array}$ & $\begin{array}{l}0.212 \\
1.840\end{array}$ & $\begin{array}{l}-0.239 \\
-1.594\end{array}$ \\
\hline VOLAT & $\begin{array}{c}-26.012 \\
-2.286\end{array}$ & $\begin{array}{c}-16.889 \\
-3.137\end{array}$ & $\begin{array}{l}3.463 \\
1.896\end{array}$ & $\begin{array}{l}-6.005 \\
-2.239\end{array}$ & $\begin{array}{l}8.020 \\
4.178\end{array}$ \\
\hline YIELD & $\begin{array}{c}-91.285 \\
-7.667\end{array}$ & $\begin{array}{c}-15.209 \\
-3.806\end{array}$ & $\begin{array}{l}-9.447 \\
-7.400\end{array}$ & $\begin{array}{c}-17.808 \\
-5.796\end{array}$ & $\begin{array}{l}-4.000 \\
-2.420\end{array}$ \\
\hline BM & $\begin{array}{c}4.110 \\
12.385\end{array}$ & $\begin{array}{l}0.395 \\
3.156\end{array}$ & $\begin{array}{c}-0.492 \\
-10.940\end{array}$ & $\begin{array}{c}-0.747 \\
-10.858\end{array}$ & $\begin{array}{l}-0.173 \\
-4.431\end{array}$ \\
\hline LEV & $\begin{array}{l}4.013 \\
3.393\end{array}$ & $\begin{array}{c}2.816 \\
13.555\end{array}$ & $\begin{array}{l}-0.163 \\
-1.457\end{array}$ & $\begin{array}{l}-0.537 \\
-2.334\end{array}$ & $\begin{array}{l}0.256 \\
2.698\end{array}$ \\
\hline Pseudo $R^{2}$ & 0.557 & 0.152 & 0.163 & 0.095 & 0.083 \\
\hline
\end{tabular}

For each variable, the first (second) row reports the time-series mean ( $t$-statistic) of the cross-sectional coefficients. The average number of observations per year is 2,059. The sample period is 1982-2001. "Holding" is the level of institutional ownership at the end of the third fiscal quarter. "Trading" is the absolute value of the change in institutional ownership during the nine months starting at the beginning of the fourth quarter. "Extreme" is an indicator variable that equals one for firm-years in the bottom or top deciles of accruals in that year. "High" is an indicator variable that equals one for firms in the top accruals decile. "Low" is an indicator variable that equals one for firms in the bottom decile. The other variables are described in Table 2. 
Figure 1

The Accruals Anomaly over Time

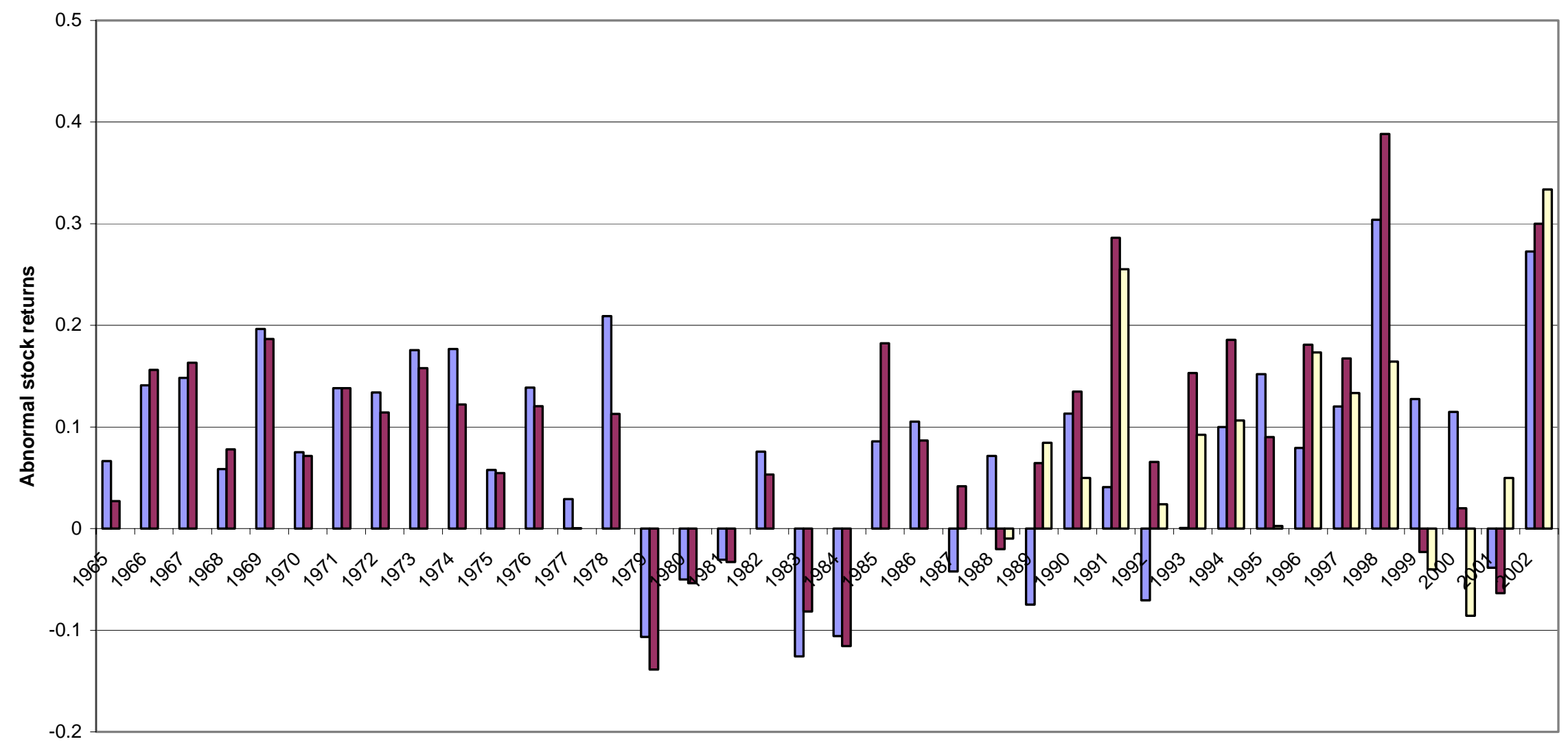

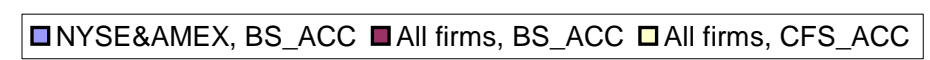

The figure reports the time series of abnormal zero-investment portfolio returns for three combinations of sample/accruals measure. Each portfolio consists of long positions in low accruals firms (lowest decile) and short positions in high accruals firms (highest decile). Abnormal return is measured as the difference between the firm's return and the contemporaneous return on a matched portfolio based on size (five quintiles) and book-to-market (five quintiles for each size quintile). Returns are measured from May first through April 30 of the following year.

$B S \_A C C\left(C F S \_A C C\right)$ is a measure of accruals using information from the balance sheet (cash flow statement). 
Figure 2

\section{Statistical Significance of a Profitable Accruals Strategy as a Function of Portfolio Size}

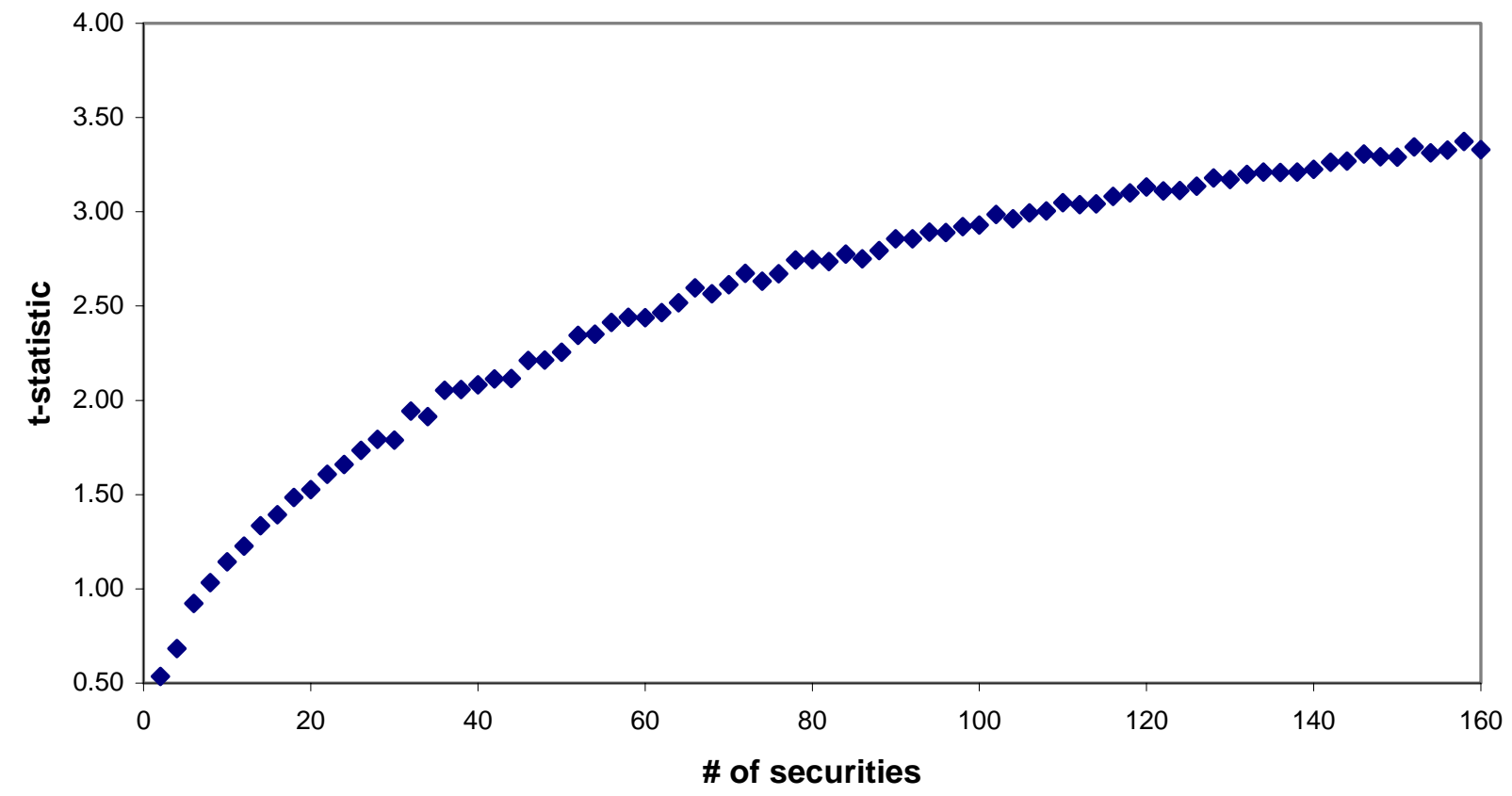

This figure plots the mean (over 500 replications) of the $t$-statistic associated with the time-series mean of abnormal portfolio return during the period 1965-2002, as a function of the number of securities in the portfolio (n). The strategy takes equal-weight long positions in $0.5 * \mathrm{n}$ firms selected randomly from the low decile of accruals each year, and short positions in $0.5^{*} \mathrm{n}$ firms from the high accruals decile. Abnormal return is measured as the difference between the firm's return and the contemporaneous return on a matched portfolio based on size (five quintiles) and book-to-market (five quintiles for each size quintile). Returns are measured from May first through April 30 of the following year. 
Figure 3

Probability of Positive Abnormal Return from Trading on Accruals Information as a Function of Portfolio Size

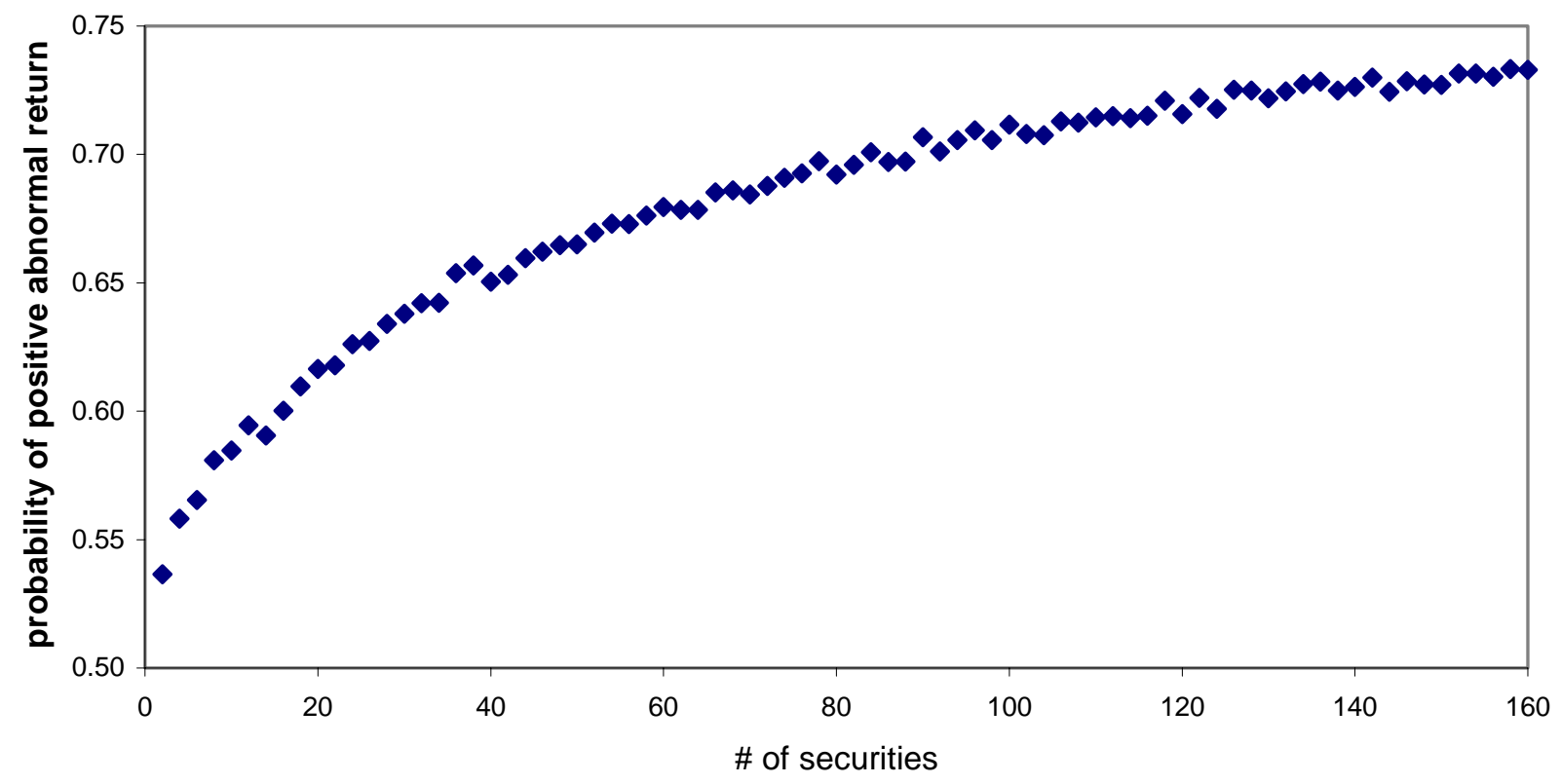

This figure plots the mean (over 500 replications) of the relative frequency of years during the period 1965-2002 in which the accruals strategy resulted in positive abnormal returns in the subsequent year, as a function of the number of securities in the portfolio (n). The strategy takes equal-weight long positions in $0.5 * \mathrm{n}$ firms selected randomly from the low decile of accruals each year, and short positions in $0.5 * \mathrm{n}$ firms from the high accruals decile. Abnormal return is measured as the difference between the firm's return and the contemporaneous return on a matched portfolio based on size (five quintiles) and book-to-market (five quintiles for each size quintile). Returns are measured from May first through April 30 of the following year. 